University of Nebraska - Lincoln

DigitalCommons@University of Nebraska - Lincoln

Publications from USDA-ARS / UNL Faculty

U.S. Department of Agriculture: Agricultural

Research Service, Lincoln, Nebraska

$12-1980$

\title{
Ratoon Stunting Disease of Sugarcane: Isolation of the Causal Bacterium
}

Michael J. Davis

USDA-ARS

A. Graves Gillaspie

USDA-ARS

Russell W. Harris

USDA-ARS

Roger H. Lawson

USDA-ARS

Follow this and additional works at: https://digitalcommons.unl.edu/usdaarsfacpub

Part of the Agricultural Science Commons

Davis, Michael J.; Gillaspie, A. Graves; Harris, Russell W.; and Lawson, Roger H., "Ratoon Stunting Disease of Sugarcane: Isolation of the Causal Bacterium" (1980). Publications from USDA-ARS / UNL Faculty. 985. https://digitalcommons.unl.edu/usdaarsfacpub/985

This Article is brought to you for free and open access by the U.S. Department of Agriculture: Agricultural Research Service, Lincoln, Nebraska at DigitalCommons@University of Nebraska - Lincoln. It has been accepted for inclusion in Publications from USDA-ARS / UNL Faculty by an authorized administrator of DigitalCommons@University of Nebraska - Lincoln. 


\section{Ratoon Stunting Disease of Sugarcane: Isolation of the Causal Bacterium}

Abstract. A small coryneform bacterium was consistently isolated from sugarcane with ratoon stunting disease and shown to be the causal agent. A similar bacterium was isolated from Bermuda grass. Both strains multiplied in sugarcane and Bermuda grass, but the Bermuda grass strain did not incite the symptoms of ratoon stunting disease in sugarcane. Shoot growth in Bermuda grass was retarded by both strains.

Ratoon stunting disease (RSD) of sugarcane (Saccharum interspecific hybrids) occurs worldwide and causes significant yield losses, especially when sugarcane is stressed by lack of water (l). A virus was originally thought to cause RSD, but in 1973 a small coryneform bacterium was implicated as the causal agent $(2,3)$. The bacterium was

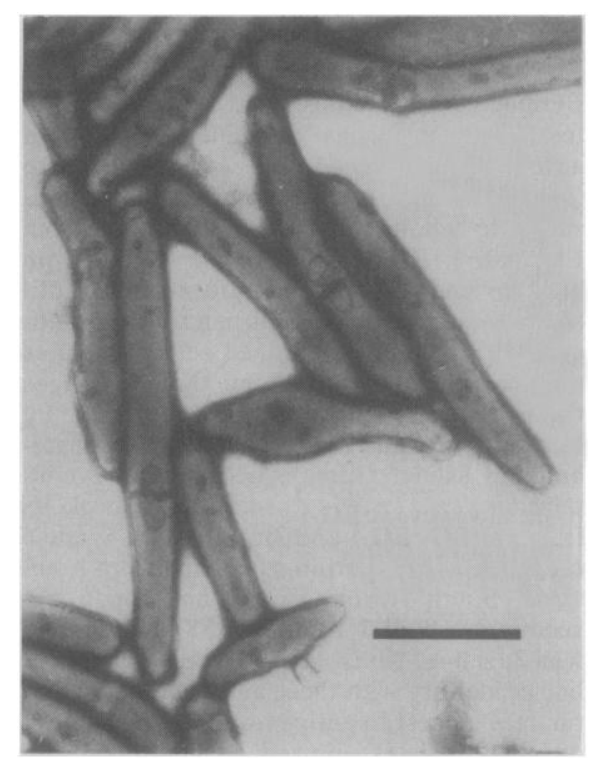

Fig. 1. Transmission electron micrograph of RSD bacteria from culture negatively stained with 1 percent phosphotungstate $(p \mathrm{H} \mathrm{7.0)}$ The bacteria resemble those seen in fibrovascular extracts (3) and expressed juice (2) of sugarcane with RSD. Scale bar, $1 \mu \mathrm{m}$. observed in expressed cane juices and xylem exudates by phase-contrast and dark-field microscopy and in extracted fibrovascular fluids and ultrathin sections of vascular bundles by electron microscopy. That the RSD-associated bacterium was the causal agent soon became widely accepted, even though the bacterium had not been isolated in axenic culture (4).

We have now isolated the RSD-associated bacterium in axenic culture and tion, we have found that a disease which stunts Bermuda grass [Cynodon dactylon (L.) Pers.] is caused by a similar bacterium. The simultaneous occurrence in Bermuda grass with witches-broom symptoms of a bacterium morphologically resembling the RSD bacterium and a mycoplasma-like organism was previously described (5).

Diagnosis of RSD is difficult because internal symptoms do not develop in all sugarcane cultivars; the only external symptom is a nonspecific stunting associated with water stress. Thus, biological assays and serological tests have been used for diagnosis. As biological assays for RSD we used (i) the development of salmon-pink discoloration in the stem tissues just below the meristematic area in young plants of sugarcane cultivar $\mathrm{CP}$ 44-101 (6), (ii) orange-red discoloration of the vascular bundles at the nodes of mature cane (I), and (iii) wilting of sorhave shown that it causes RSD. In addi-
ghum-Sudan grass hybrid NB 280 S uprights (7). In addition, antiserum to RSD bacteria extracted from diseased sugarcane was used throughout the study in an indirect fluorescent antibody staining test to identify isolates ( 8 ).

The RSD bacterium was first isolated from inoculated hybrid NB 280 S, which supports large populations of the bacterium (9). Internodes of mature plants were surface-sterilized (10), and fibrovascular fluid was obtained by vacuum extraction (3). The presence of the bacterium in the fluids was confirmed by phase-contrast microscopy $(\times 1250)$, and plates containing semisolid media were inoculated with $10-\mu l$ portions of the fluid diluted two to ten times with $0.01 M$ phosphate buffer ( $p \mathrm{H} \mathrm{6.8)}$. After testing numerous formulations for their ability to support axenic cultures of RSD bacteria, we developed the SC medium (II). Colonies raised on the SC medium were 0.1 to $0.3 \mathrm{~mm}$ in diameter, circular with entire margins, convex, and nonpigmented after 2 weeks of aerobic incubation at $30^{\circ} \mathrm{C}$.

We subsequently isolated the bacterium from infected sugarcane from Louisiana, Brazil, South Africa, and Japan. The bacterium was consistently isolated from sugarcane with RSD but not from healthy sugarcane (Table 1). Attempts were made to isolate the bacterium from fibrovascular fluids obtained from sugar-

Table 1. Isolation of the RSD bacterium. Plants of 20 sugarcane cultivars varying widely in susceptibility to RSD were sampled from Louisiana field plots. Although not completely effective for the elimination of RSD (14), heat treatment of seed pieces was used to establish a "healthy" plot with a low incidence of RSD. Two mature plants of each cultivar were sampled from the healthy plot and a "diseased" plot. A portion of the cane from each plant was bioassayed for RSD (6); the remainder was washed with soap and water, rinsed with water, washed with 70 percent ethanol, and flamed. An internodal section approximately $12 \mathrm{~cm}$ in length was aseptically excised and placed in a sterile, 50-ml conical tube for centrifugation at $1000 \mathrm{rev} / \mathrm{min}$ for 1 minute to extract fibrovascular fluid. The presence of bacteria in the extracts was determined by phase-contrast microscopy $(\times 1250)$, and the SC medium was inoculated with serial tenfold dilutions of each extract to $1: 10^{-8}$.

\begin{tabular}{|c|c|c|c|c|}
\hline \multirow[b]{2}{*}{ Plot } & \multirow[b]{2}{*}{$\begin{array}{c}\text { Result } \\
\text { of } \\
\text { RSD } \\
\text { bio- } \\
\text { assay }\end{array}$} & \multicolumn{3}{|c|}{ Number of plants } \\
\hline & & $\begin{array}{l}\text { To- } \\
\text { tal }\end{array}$ & $\begin{array}{c}\text { Bac- } \\
\text { teria } \\
\text { ob- } \\
\text { served }\end{array}$ & $\begin{array}{c}\text { Bac- } \\
\text { teria } \\
\text { iso- } \\
\text { lated }\end{array}$ \\
\hline & $\begin{array}{l}\text { Positive } \\
\text { Negative }\end{array}$ & $\begin{array}{l}29 \\
10\end{array}$ & $\begin{array}{r}26 \\
4\end{array}$ & $\begin{array}{r}26 \\
5\end{array}$ \\
\hline tealuiny & $\begin{array}{l}\text { Positive } \\
\text { Negative }\end{array}$ & $\begin{array}{r}4 \\
36\end{array}$ & $\begin{array}{l}3 \\
2\end{array}$ & $\begin{array}{l}3 \\
2\end{array}$ \\
\hline
\end{tabular}


cane grown in field plots in Louisiana. The bacterium was isolated from 29 of the 33 plants with a positive bioassay for RSD (6) and 7 of the 46 plants with a negative biosassay. Apparently, the RSD bioassay not only takes longer (up to 14 weeks) but is no more sensitive for diagnosis than the isolation of the bacterium. Microscopic observation of the bacterium was correlated with its isolation. It was isolated from 34 of 36 plants when bacteria were observed (by phase-contrast microscopy) in the extracts and from 4 of 44 plants when bacteria were not observed.

The only known host of the RSD bacterium in nature is sugarcane; however,

Table 2. Ability of sugarcane and Bermuda grass isolates to incite RSD in sugarcane. Approximately equal numbers of plants were inoculated with two isolates from each original host. The hosts were one sugarcane plant each from South Africa (SA), Brazil (BR), Louisiana (LA), and Japan (JP) and two Bermuda grass plants from Taiwan (BG 1 and BG 2 isolates). The isolates were cloned three times from single colonies before being grown in S8 broth (11) for 7 to 14 days. Freshly cut, single-node seed pieces of sugarcane cultivar CP: 44-101 were dipped in suspensions of the isolates $\left(A_{5 e 0}=0.1\right.$ to 0.2$)$ in either S8 broth or $0.01 M$ phosphate buffer $(p H$ 6.9) for 30 seconds and allowed to stand for 20 minutes. The seed pieces were planted in vermiculite and grown, and symptoms of RSD were read either while they were young plants (8 to 14 weeks) or after their transplantation to soil and growth to maturity (28 to 33 weeks). Plants inoculated with phosphate buffer or S8 broth and noninoculated plants served as controls. Isolation attempts on SC medium were made at the time of symptom reading. Numbers in parentheses give the number of reisolation attempts in which the cultures became overgrown with contaminants and therefore unreadable.

\begin{tabular}{|c|c|c|c|c|}
\hline \multirow{2}{*}{$\begin{array}{l}\text { Inocu- } \\
\text { lum }\end{array}$} & \multicolumn{2}{|c|}{$\begin{array}{l}\text { Plants } \\
\text { developing } \\
\text { symptoms }\end{array}$} & \multicolumn{2}{|c|}{$\begin{array}{l}\text { Number of } \\
\text { positive } \\
\text { reisolations }\end{array}$} \\
\hline & $\begin{array}{c}\text { Im- } \\
\text { ma- } \\
\text { ture } \\
\text { plants }\end{array}$ & $\begin{array}{c}\text { Ma- } \\
\text { ture } \\
\text { plants }\end{array}$ & $\begin{array}{c}\text { Im- } \\
\text { ma- } \\
\text { ture } \\
\text { plants }\end{array}$ & $\begin{array}{l}\text { Ma- } \\
\text { ture } \\
\text { plants }\end{array}$ \\
\hline $\begin{array}{l}\text { SA iso- } \\
\text { lates }\end{array}$ & $22 / 23$ & $33 / 33$ & $21(1)$ & $31(2)$ \\
\hline $\begin{array}{l}\text { BR iso- } \\
\text { lates }\end{array}$ & $25 / 27$ & $37 / 37$ & $22(4)$ & 37 \\
\hline $\begin{array}{l}\text { LA iso- } \\
\text { lates }\end{array}$ & $17 / 21$ & $26 / 28$ & $16(2)$ & $24(2)$ \\
\hline $\begin{array}{l}\text { JP iso- } \\
\text { lates }\end{array}$ & $13 / 18$ & $20 / 20$ & $9(3)$ & 16 \\
\hline $\begin{array}{l}\text { BG } 1 \text { iso- } \\
\text { lates }\end{array}$ & $0 / 17$ & $0 / 20$ & $1(8)$ & 2 \\
\hline $\begin{array}{l}\text { BG } 2 \text { iso- } \\
\text { lates }\end{array}$ & $0 / 29$ & $0 / 35$ & $4(6)$ & $2(3)$ \\
\hline $\begin{array}{c}\text { Buffer } \\
\text { only }\end{array}$ & $0 / 5$ & $0 / 7$ & 0 & 0 \\
\hline $\begin{array}{l}\text { S8 medi- } \\
\text { um }\end{array}$ & $0 / 11$ & $0 / 9$ & 0 & O \\
\hline $\begin{array}{l}\text { Not inocu- } \\
\text { lated }\end{array}$ & $0 / 4$ & $0 / 12$ & 0 & 0 \\
\hline
\end{tabular}

a bacterium resembling the RSD one was observed in Bermuda grass from Taiwan (5). These plants were also infected with a mycoplasma-like organism and had witches-broom symptoms. We isolated the bacterium from two of these plants. Internodal pieces of the stems were surface-sterilized, and fluids were expressed from freshly cut ends with forceps and blotted onto the SC medium. The bacteria grew readily, and faster than those isolated from sugarcane. The colonies reached a diameter of 0.5 to 1.0 $\mathrm{mm}$ in 2 weeks and were convex and circular with entire margins. Unlike colonies of the RSD bacterium, they displayed a yellow nondiffusible pigment.

The two strains of bacteria were morphologically and ultrastructurally indistinguishable. When smears from the cultures were examined with phase-contrast microscopes, predominantly single and paired cells joined end-to-end were observed, but short, branched filaments were also noted. The paired cells were often aligned in a " $\mathrm{V}$," which is common among coryneform bacteria (12). By transmission electron microscopy, negatively stained cells measured 0.25 to 0.35 $\mu \mathrm{m}$ in diameter and 1 to $4 \mu \mathrm{m}$ in length and often appeared to be undergoing septate division (Fig. 1). The bacteria were usually straight or slightly curved rods, but some cells were swollen at one end or in the middle. Mesosomes were often present and sometimes appeared to be associated with septum formation. Examination of ultrathin sections of cultured bacteria and bacteria from diseased plants disclosed no differences in cell wall structure (9).

The Bermuda grass bacterium was not distinguishable from the sugarcane bacterium by indirect fluorescent antibody staining. All the isolates from sugarcane reacted identically in agar-gel double diffusion tests, but the Bermuda grass isolates showed partial identity with sugarcane isolates and identity with each other (Fig. 2).

Only the sugarcane bacterium incited RSD in sugarcane cultivar CP 44-101 (Table 2). Eight isolates of sugarcane bacterium, including two each from the United States, Brazil, South Africa, and Japan, incited vascular discoloration in a total of 71 of 88 immature plants and 116 of 118 mature plants. The bacterium was reisolated from 68 of 79 immature plants and 108 of 114 mature plants. The Bermuda grass bacterium was reisolated from 5 of 32 immature plants and 4 of 52 mature plants. Furthermore, all 36 isolated from Louisiana sugarcane incited RSD symptoms in immature plants.

Both the sugarcane and Bermuda grass bacterial strains stunted Bermuda grass, but no witches-broom symptoms were observed. Four isolates from each of the strains were used in the inoculations. Five months after inoculation with isolates from either species, Bermuda grass plants grew shoots whose mean fresh weight was significantly less $(P<.01$, chi-square test $)$ than that of shoots from buffer-inoculated controls. The weights were 1.53 $\mathrm{g}$ (59 plants), $1.90 \mathrm{~g}$ (53 plants), and 3.25 $\mathrm{g}$ (22 plants) for shoots of Bermuda grass inoculated with Bermuda grass isolates, sugarcane isolates, and buffer, respectively. The Bermuda grass isolates were reisolated from 56 of 59 inoculated plants whereas the sugarcane isolates were reisolated from only 22 of 53 inoculated plants. The bacteria were observed in juice expressed from the shoots in 53 of 59 plants inoculated with Bermuda grass isolated and 17 of 53 plants inoculated with sugarcane isolates. Bacteria were not observed in, or isolated from, the controls.

All 20 sorghum-Sudan grass uprights wilted 7 weeks after inoculation with a Louisiana sugarcane isolate, and the bacterium was reisolated from each plant. None of the 19 uprights inoculated with a Bermuda grass isolate wilted during this period, but the bacterium was reisolated from all of them. The 17 up-

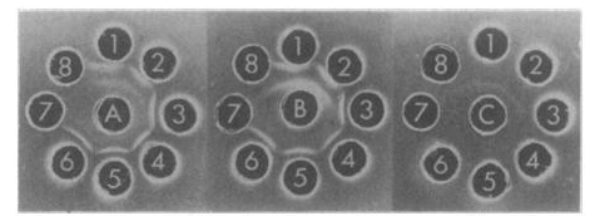

Fig. 2. Serological reactions of sugarcane and Bermuda grass isolates in gel double-diffusion tests. The gel plates contained 0.5 percent agarose, $0.15 \mathrm{M} \mathrm{NaCl}$, and $0.01 M$ phosphate ( $p$ H 7.2). Center wells contained rabbit antiserum to whole cells: (A) RSD isolate from Louisiana, (B) Bermuda grass isolate from Taiwan, and (C) Bermuda grass isolate antiserum absorbed with Louisiana isolate antigen. Outside wells contained cells of isolates that had been disrupted by three passages through a French press, concentrated by freeze-drying, and resuspended in phosphatebuffered saline. Outside wells 1 and 2 contained isolates from two Bermuda grass plants from Taiwan (BG 1 and 2); wells 3, 4, 5, and 6 contained isolates from sugarcane from Louisiana, South Africa, Brazil, and Japan, respectively. Well 7 contained S8 medium and well 8, saline. All isolates showed a confluent line of identity with these antiserums (precipitin lines closest to antigen wells). The Bermuda grass isolates showed an additional line closer to the antiserum well with homologous antiserum, as in (B), which is retained after absorption with a RSD antigen, as in (C). Louisiana isolate antiserum absorbed with Bermuda grass isolate antigen produced no visible precipitin lines (not shown). 
rights inoculated with media alone did not wilt, and no bacteria were isolated from any of them. In a separate test, sugarcane isolates from Louisiana, Brazil, South Africa, and Japan incited wilting of uprights, but Bermuda grass isolates again did not.

Although no serological relation has been found between the RSD bacterium and numerous other species of bacteria (i3), including Corynebacterium tritici, C. rathayi, C. flaccumfaciens, C. michiganense, $C$. nebraskense, $C$. fascians, and $C$. insidiosum, the sugarcane and Bermuda grass strains morphologically appear to be members of the group of coryneform bacteria pathogenic to plants. All the sugarcane and Bermuda grass isolates were aerobic, nonmotile, Grampositive, non-acid-fast, catalase-positive, and oxidase-negative. Apparently the two strains are closely related species or are different pathovars of the same species of a xylem-inhabiting pathogen. Cultivation of the RSD causal agent in vitro will greatly enhance efforts to study and control the disease.

Michael J. Davis Department of Plant Pathology, Cook College, New Jersey Agricultural Experiment Station, Rutgers

University, New Brunswick 08903

A. Graves Gillaspie, Jr. RUSSELL W. HARRIS ROGER H. LAWSON U.S. Department of Agriculture, Beltsville, Maryland 20705

\section{References and Notes}

1. D. R. L. Steindl, in Sugarcane Diseases of the World, J. P. Martin, E. V. Abbott, C. G. Hughes, Eds. (Elsevier, Amsterdam, 1961) p. 433.

2. A. G. Gillaspie, Jr., R. E. Davis, J. F. Worley, Plant Dis. Rep. 12, 987 (1973); K. Maramorosch, B. Plavsic-Banjac, J. Bird, L. J. Liu, Phytopathol. Z. 77, 270 (1973).

3. D. S. Teakle, P. M. Smith, D. R. L. Steindl, Aust. J. Agric. Res. 24, 869 (1973).

4. D. S. Teakle, Proc. Int. Soc. Sugar-Cane Technol. 15, 225 (1974).

5. T. A. Chen, H. J. Su, B. C. Raju, W. C. Huang Proc. Am. Phytopathol. Soc. 4, 171 (Abstr.) (1977).

6. A. G. Gillaspie, Jr., J. E. Irvine, R. L. Steere, Phytopathology 56, 1426 (1966).

7. G. T. A. Benda, Proc. Am. Soc. Sugar-Cane G. T. A. Benda, Proc. Am. Soc. Sugar-Cane
Technol. 1, 39 (1971). An upright is a two-node cutting planted vertically in the soil. The bud at cutting planted vertically in the soil. The bud at the lower node is removed so that only roots are
produced, and the shoot develops from the bud produced, and the shoot develops from the bud at the upper node.

8. A. G. Gillaspie, Jr., Phytopathology 68, 529 (1978); R. W. Harris and A. G. Gillaspie, Jr. Plant Dis. Rep. 62, 193 (1978)

9. J. F. Worley and A. G. Gillaspie, Jr., Phytopathology 65, 287 (1975)

10. M. J. Davis, A. H. Purcell, S. V. Thomson, Science 199, 75 (1978)

11. The SC medium consists of distilled water, 1000 $\mathrm{ml}$; cornmeal agar, $17 \mathrm{~g}$; papaic digest of soy meal, $8 \mathrm{~g} ; \mathrm{K}_{2} \mathrm{HPO}_{4}, 1 \mathrm{~g} ; \mathrm{KH}_{2} \mathrm{PO}_{4}, 1 \mathrm{~g} ; \mathrm{MgSO}_{4}$. $7 \mathrm{H}_{2} \mathrm{O}, 0.2 \mathrm{~g}$; bovine hemin chloride $(15 \mathrm{ml}$ of a 0.1 percent solution in $0.05 \mathrm{~N} \mathrm{NaOH}), 15 \mathrm{mg}$; bo0.1 percent solution in $0.05 \mathrm{~N} \mathrm{NaOH}), 15 \mathrm{mg}$; bovine serum albumin fraction $5(10 \mathrm{ml}$ of a 20 pe 50 pequeous solution), $2 \mathrm{~g}$, glucose $(1.0 \mathrm{ml}$ of 50 percent aqueous solution), $0.5 \mathrm{~g}$, and cystein (free base, $10 \mathrm{ml}$ of a 10 percent aqueous solution), $1 \mathrm{~g}$. The S8 medium (Table 2) is the same except that cornmeal agar is omitted and there are $1.5 \mathrm{~g}$ of $\mathrm{KH}_{2} \mathrm{PO}_{4}$ and $0.5 \mathrm{~g}$ of $\mathrm{K}_{2} \mathrm{HPO}_{4}$. The bovine serum albumin, cysteine, and glucose soutions were filter-sterilized and added to the autoclaved portion at $50^{\circ} \mathrm{C}$. The $p \mathrm{H}$ was adjusted to 6.6 with $1 N \mathrm{NaOH}$ or $\mathrm{HCl}$.

12. K. Komagata, K. Yamada, H. Ogawa, J. Gen Microbiol. 15, 243 (1969).

13. M. J. Davis, R. F. Whitcomb, A. G. Gillaspie, Jr., in The Prokaryotes, M. P. Starr, H. Stolp, H. G. Truper, A. Balows, H. G. Schlegel, Eds (Springer-Verlag, New York, in press).
14. G. T. A. Benda and C. Ricaud, Proc. Int. Soc. Sugar-Cane Technol. 16, 483 (1978).

15. Paper of the Journal Series, New Jersey Agricultural Experiment Station (NJAES), Cook College, Rutgers University. This work was performed as a part of NJAES project 11900 and was supported by NJAES and the USDA-SEA Competitive Grants Program.

10 July 1980; revised 22 September 1980 